\title{
Wykorzystanie portfolio w procesie kształcenia nauczycieli: rys historyczny oraz podsumowanie doświadczeń
}

\begin{abstract}
Streszczenie
Celem niniejszego artykułu jest przypomnienie koncepcji portfolio w kształceniu nauczycieli oraz spojrzenie na możliwości użycia tego narzędzia w polskich realiach. W pierwszej części przedstawiono historię i stan wiedzy na ten temat w innych krajach, a w drugiej zaprezentowano doświadczenia zaadaptowania portfolio nauczycielskiego do potrzeb przygotowania nauczycieli języka angielskiego w programie Graduate Programme of Teaching English to Young Learners na Uniwersytecie Warszawskim.
\end{abstract}

\section{Słowa kluczowe:}

portfolio nauczycielskie, kształcenie nauczycieli, refleksja, narzędzia oceny nauczycieli

\section{Abstract}

The aim of the paper is twofold. It presents an overview of various conceptualisations of teaching portfolio and their historical development. It also describes the process of creating the teaching portfolio at the teacher

${ }^{1}$ Katarzyna Brzosko-Barratt, Wydział Pedagogiczny, Uniwersytet Warszawski, Polska, e-mail: k.brzosko-barratt@uw.edu.pl, ORCID ID: https://orcid.org/0000-0002-5636-8416. 
education programme focused on early language learning and CLIL teaching offered at the University of Warsaw. The paper ends with some final conclusions regarding the process of adaptation of teaching portfolio within the teacher education system in Poland.

\section{Keywords:}

teaching portfolio, teacher education, reflection, teacher assessment tools

\section{WSTĘP}

W związku z poszukiwaniem nowych metod kształcenia, w większym stopniu skierowanych na indywidualizację procesu nauczania i oceniania, zainteresowanie wykorzystaniem portfolio znacząco wzrosło na wyższych uczelniach w Polsce. Obecnie w wielu krajach Europy i świata portfolio jest stosowane powszechnie na wszystkich etapach kształcenia i na różnych kierunkach studiów wyższych. Literatura przywołuje przykłady użycia portfolio, począwszy zarówno od studiów artystycznych, technicznych, przyrodniczych, medycznych, na społecznych, nauczycielskich, jak i językowych skończywszy (Meeus, Questier i Derks, 2006). Chociaż te portfolio różnią się, ze względu na charakterystykę studiów lub na formę (portfolio papierowe albo elektroniczne), można znaleźć w nich ważne cechy wspólne. Są to: skupienie na uczącym się, ukierunkowanie na kompetencje, skoncentrowanie na aktywnościach i wykorzystanie refleksji (Meeus, Questier i Derks, 2006). Z uwagi na bardzo pojemny charakter tego narzędzia i jego dużą popularność należy usystematyzować podstawowe pojęcia.

Badacze belgijscy: Meeus, Petegem i Van Looy (2006) zauważyli, że portfolio wpisuje się w pewną ciągłość kształcenia na wyższej uczelni - od okresu rekrutacji po zakończenie studiów. Etapy te zostały przedstawione na schemacie 1, ukazującym sposoby wykorzystania portfolio na studiach wyższych.

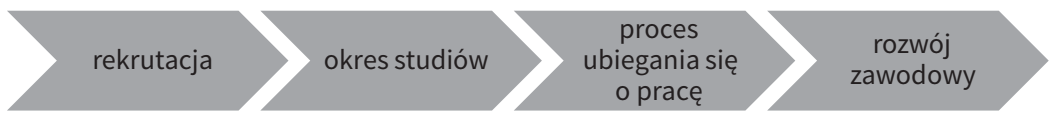

Schemat 1. Wykorzystanie portfolio na różnych etapach edukacji

Według tego schematu portfolio może być użyte w procesie rekrutacji dla oceny kompetencji zdobytych wcześniej zarówno na drodze edukacji formalnej, jak i nieformalnej, następnie portfolio jest używane do różnych celów w czasie trwania studiów. Może ono być stosowane na przykład na poszczególnych zajęciach lub 
podczas oceny kompetencji zdobytych w trakcie całego toku studiów. Kolejnym sposobem implementacji portfolio jest jego rola dokumentująca i oceniająca konieczne kwalifikacje na potrzeby przyszłych pracodawców w czasie ubiegania się o pracę. Ostatecznie portfolio ma swoją kontynuację podczas całego życia zawodowego, dokumentując ciągły rozwój zawodowy studenta po zakończeniu studiów.

Różne sposoby wykorzystania portfolio determinują jego format i charakter. Z jednej strony portfolio spełnia rolę rozbudowanego CV, jak na przykład w portfolio, którego celem jest proces rekrutacji na studia lub do pracy, skupiającym się jedynie na ocenie kompetencji kandydata ubiegającego się o przyjęcie na podstawie wcześniej nabytej wiedzy i umiejętności. Takie portfolio składa się z głównie z różnych form samooceny popartej odpowiednią dokumentacją. Natomiast w przypadku portfolio wykorzystywanego w trakcie studiów - jego rola jest już znacznie bardziej urozmaicona. Staje się ono wtedy ważnym elementem samego procesu kształcenia oraz oceniania, często zmieniającym gruntownie jego charakter.

Jedną z dziedzin, która ma szczególnie długą tradycję we wdrażaniu portfolio, jest kształcenie i rozwój nauczycieli, czego dowodem są różne koncepcje tego narzędzia funkcjonujące na całym świecie przez ostatnie 20-30 lat. Portfolio nauczycielskie obejmuje wszystkie etapy wymienione na schemacie 1. Jest ono stosowane do oceny kompetencji w procesie rekrutacji, w czasie toku studiów, podczas ubiegania się o pracę oraz po zakończeniu edukacji jako narzędzie wykorzystywane do dalszego rozwoju zawodowego. Obecnie większość tych portfolio jest przygotowywana w formie elektronicznej.

Celem niniejszej artykułu jest przypomnienie koncepcji portfolio w kształceniu nauczycieli oraz spojrzenie na możliwości użycia tego narzędzia w polskich realiach. W pierwszej części przedstawiono historię i stan wiedzy na ten temat w innych krajach, a w drugiej zaprezentowano doświadczenia zaadaptowania portfolio nauczycielskiego do potrzeb przygotowania nauczycieli języka angielskiego w programie Graduate Programme of Teaching English to Young Learners na Uniwersytecie Warszawskim.

Literatura i przykłady wykorzystania portfolio, które były inspiracją do powstania koncepcji portfolio GPTE, pochodziły głównie z: USA, Holandii, Szwecji i Belgii oraz Austrii. Przegląd literatury wykazał również, że pojawiają się próby adaptowania portfolio w innych krajach, np. w Chinach, gdzie proces kształcenia z zastosowaniem portfolio był do niedawna uznawany za odległy i obcy. Wszystkie badania ukazują zarówno kompleksowość tego narzędzia, jak i uwarunkowania, które w dużym stopniu wpływają na efektywność jego wykorzystania. Obecne 
podejście do portfolio jest zmodyfikowane w porównaniu z końcem XX wieku, ale by w pełni zrozumieć nowe tendencje i obecne dylematy w tej dziedzinie, należy spojrzeć na rozwój koncepcji portfolio w ciągu minionych lat.

\section{POCZĄTKI PORTFOLIO W PROCESIE KSZTALCENIA NAUCZYCIELI}

Zainteresowanie wykorzystaniem portfolio w kształceniu nauczycieli pojawiło się w latach 80. zeszłego stulecia w Stanach Zjednoczonych i wkrótce potem w innych krajach Europy i świata. Rozpoczęto wtedy pierwsze próby adaptacji portfolio jako narzędzia towarzyszącego procesowi uczenia się i oceniania przyszłych kadr nauczycielskich. Wielu współczesnych badaczy podkreśla, że zainteresowanie portfolio w Stanach Zjednoczonych należy łączyć z działaniami związanymi z profesjonalizacją zawodu nauczyciela i z próbami określenia podstawy lub trzonu jego wiedzy oraz szerszej dyskusji na temat sposobów jej zdobywania i oceniania. Obecnie działania z tego okresu są często nazywane reformą opartą na standardach (ang. Standards based reform).

Pierwsze próby użycia portfolio w USA skupione było wokół Fundacji Carnegie i Uniwersytetu Stanforda, a zostały zainicjowane przez takich badaczy, jak Lee Shulman oraz Gary Sykes pod nazwą Task Force on Teaching as a Profession, tzw. TAP w 1986 roku. Praca tej grupy ekspertów doprowadziła do stworzenia nowych standardów oraz nowych form oceniania nauczycieli, zastępujących lub uzupełniających bardziej tradycyjne metody. Portfolio zostało uznane za najlepsze narzędzie do oceny umiejętności nauczycielskich według profesjonalnych standardów nauczycielskich. Zdaniem Shulmana (1986) portfolio dawało bowiem możliwości oceny złożoności warsztatu nauczyciela poprzez pełniejszą prezentację procesu kształcenia i zademonstrowanie warsztatu nauczycielskiego. Portfolio w odróżnieniu od egzaminów nadających uprawnienia było więc traktowane jako dokładniejsza metoda oceniania, zgadzająca się z konstruktywistyczną teorią uczenia, pozwalającą na zachowanie indywidualności, otwartości, wspierającą współpracę, dialog oraz refleksję. Efektem działań tej grupy było stworzenie portfolio w procesie nadawania ogólnokrajowej certyfikacji dla nauczycieli pracujących w zawodzie przez wiele lat, a starających się o podniesienie swoich kwalifikacji - National Board for Professional Teaching Standards (portfolio NBPTS). Według pomysłodawców siła portfolio polegała na tym, że oparte było na rzeczywistych i konkretnych działaniach nauczyciela, które lepiej prezentują jego warsztat niż tradycyjne egzaminy, jedynie sprawdzające wiedzę teoretyczną oderwaną od realiów nauczycielskich. Portfolio miało przyczynić się nie tylko do 
rozwoju indywidualnego poszczególnych nauczycieli, którzy przystępowali do certyfikacji, ale również do rozwoju profesjonalizacji tego zawodu.

Chociaż pierwsze egzemplarze portfolio z lat 90. ograniczały się często do gromadzenia oraz prezentacji różnego typu dokumentów i artefaktów bez stosownych komentarzy i refleksji (Wolf, 1991), to współczesne przykłady portfolio NBPTS są niezwykle szczegółowymi narzędziami, tworzonymi według ściśle określonych wymogów, które są sprawdzane przez specjalnie wyszkolonych ewaluatorów. Portfolio te składają się z opisów, analiz i refleksji, popartych wybranymi przykładami nagranych lekcji (wideo), prac uczniów, zbiorów artefaktów, pomocy dydaktycznych, udokumentowanych przez 15 miesięcy. Przy tworzeniu własnych portfolio kandydaci muszą zaprezentować szczegółową znajomość uczniów i ich potrzeb, zaplanować cele kształcenia, biorąc pod uwagę ich indywidualne potrzeby oraz możliwości. Następnie opracować szczegółowo proces uczenia oraz oceniania, po czym dokonać refleksji oraz zaplanować następne cele kształcenia na podstawie efektów oraz refleksji. Portfolio takie jest więc ustrukturyzowanym narzędziem przeznaczonym do oceny wiedzy i kompetencji nauczyciela w świetle standardów przedmiotowych oraz pięciu zasad, uznanych jako kluczowe w pracy nauczyciela. Są to: 1) Nauczycielom zależy na dobru uczniów i na ich postępach w nauce; 2) Nauczyciele znają dobrze swój przedmiot, zarówno pod względem treści, jak i sposobów jego przekazywania; 3) Nauczyciele są odpowiedzialni za kierowanie procesem kształcenia uczniów; 4) Nauczyciele obserwują i monitorują przebieg oraz wyniki swojej pracy i na tej podstawie szukają sposobów jej doskonalenia; 5) Nauczyciele współtworzą społeczność uczącą się.

Portfolio NBPTS jest wysoko postrzegane przez badaczy ze względu na ocenianie autentycznych działań nauczycielskich w określonym czasie (Ingvarson i Hattie, 2008). Badania potwierdzają, że portfolio wpływa trwale na metody i strategie uczenia nauczycieli, którzy przeszli przez 15-miesięczny proces kompilacji tego narzędzia. Podczas pracy nad portfolio nauczyciele rozwijają swoje umiejętności, takie jak: uczenie oparte na dowodach (ang. evidence based teaching), umiejętność planowania i adaptowania działań w klasie, lepsze rozumienie potrzeb dzieci ze względu na dokładniejszą analizę procesu rozwojowego i psychicznego uczniów, a także pogłębiają swoją świadomość działań i decyzji.

Dalsze ścieżki rozwoju portfolio w USA są związane z procesem standaryzacji toku kształcenia nauczycieli wchodzących do zawodu przez organizacje zajmujące się procesem akredytacji instytucji kształcących nauczycieli w USA. W tym celu powołana została organizacja, która obecnie składa się z przedstawicieli z ponad 30 stanów, o nazwie Interstate New Teacher Assessment and Support Consortium (INTASC), która wypracowała standardy oraz narzędzia oceny nauczycieli koń- 
czących studia i wchodzących do zawodu w wielu regionach w USA. Jednym z tych założeń było wspólne ustalenie wymagań przy nadawaniu wstępnych uprawnień nauczycielom. Dzięki zabiegom INTASC już pod koniec lat 90., wiele uniwersytetów wprowadziło portfolio do swoich programów kształcenia. Obecnie instytucje akredytujące programy kształcenia nauczycieli, jak National Council for Accreditation of Teacher Education (NCATE), niejako wymuszają na uniwersytetach wykorzystanie portfolio w procesie przygotowywania przyszłych pedagogów. Portfolio INTASC, podobnie jak portfolio NBPTS, jest narzędziem ustrukturyzowanym i stworzonym wokół 10 standardów kształcenia nauczycieli.

Badania portfolio inicjowanych przez standardy INTASC (Deandshere i Arens, 2003) przedstawiają jednak brak jednolitej wizji użycia tego narzędzia w procesie kształcenia, bowiem wykładowcy w adaptowaniu portfolio odczuwali presję dotyczącą akredytacji swoich programów kształcenia zgodnie ze standardami. A wykorzystanie portfolio dawało wymagane dowody, że standardy te zostały zachowane. Tymczasem badane edycje portfolio zawierały uproszczone przykłady zgodności ze standardami. Cele związane z rozwojem i procesem uczenia się nie były uznane jako nadrzędne, a analiza wykazała wiele uproszczeń i brak refleksji w pracach studentów. Badanie to wykazało również niezgodność między celami, jakie przypisywali portfolio wykładowcy oraz studenci. O ile wykładowcy zwracali głównie uwagę na kwestie programowe związane ze standardami kształcenia, o tyle studenci widzieli to narzędzie jako przydatne w demonstrowaniu swoich umiejętności przyszłym pracodawcom. Problematycznym był również system oceniania portfolio ze względu na brak jasno wypracowanych kryteriów. Takie kraje, jak Wielka Brytania czy Australia również wykorzystują portfolio do celów podsumowujących proces kształcenia nauczycieli i do sprawdzenia zgodności programu ze standardami kształcenia. Owe uproszczone wykorzystanie portfolio jest często krytykowane zarówno w USA, jak i Europie, wobec dużej sprzeczności względem pierwszych założeń, jakie jemu przypisywano, czyli narzędzia wspomagającego indywidualny rozwój nauczyciela. Obecnie wydziały korzystające z portfolio zgodnie ze standardami INTASC znacznie zmodyfikowały proces tworzenia tych narzędzi, poszerzając ich rolę poprzez większą integrację z programami kształcenia.

Podsumowując - w pierwszym okresie adaptacji portfolio w kształceniu nauczycieli można zaobserwować dwa główne kierunki jego rozwoju. Pierwszy kierunek oceniania dotyczący oceny przyszłych nauczycieli, który wpisuje się w ciąg myślenia o pewnej standaryzacji procesu kształcenia nauczycieli, oraz drugi, bardziej obiecujący, związany z indywidualnym rozwojem umiejętności nauczycielskich, przede wszystkim umiejętności refleksji i samooceny. Te dwa 
obszary stały się więc dominującymi i najczęściej były omawiane w literaturze przedmiotu.

\section{PORTFOLIO I REFLEKSJA}

Refleksja jest nieodzownym elementem kształcenia nauczycieli, dlatego badacze od wielu lat poszukują najbardziej efektywnych sposobów na rozwijanie tej umiejętności wśród nauczycieli. Portfolio, a zwłaszcza portfolio rozwoju, jest narzędziem idealnie nadającym się do postępu myślenia refleksyjnego. W związku z tym, że nie ma jednolitej koncepcji refleksji w edukacji nauczycieli, istnieje wielkie zróżnicowanie oczekiwań względem refleksji w portfolio. Najczęściej refleksja jest formułowana jako sposób systematycznego myślenia na temat własnych doświadczeń w powiązaniu z praktyką edukacyjną. W praktyce natomiast refleksja jest rozumiana jako szereg działań, takich jak: poszukiwanie alternatywnych rozwiązań w klasie, analiza tego, co się wydarzyło, i zastanowienie nad działaniami w przyszłości (Conway, 2001), poszukiwanie tego, co leży u podstaw działań edukacyjnych (Zeichner, Liston, 1985), oraz formułowanie własnych teorii (Bain, Ballentyne, Packer, Millis, 1999).

Mansvelder-Longaroux, Bejiard i Verloop (2007) zauważyli pewne oczekiwania dotyczące istoty refleksji w portfolio. Według nich jej cechą charakterystyczną jest ukierunkowanie na proces. Z jednej strony punktem wyjścia jest konkretne doświadczenie, ale z drugiej strony refleksja dotyczy porównania kontekstów i doświadczeń teraźniejszych z doświadczeniami z lat poprzednich. Refleksja w portfolio powinna również przedstawiać zmiany w myśleniu. Ma ona też często charakter tematyczny, zakładający pewien proces rozpracowywania wydarzeń i działań edukacyjnych.

Istnieje niewiele badań analizujących charakterystykę refleksji w portfolio nauczycielskich. Mansvelder-Longaroux, Bejiard i Verloop (2007) przeanalizowali prace studentów pod względem 6 elementów, które uznali za ważne w procesie refleksji nauczycielskiej. Były to: 1) retrospekcja, przypomnienie doświadczenia; 2) ewaluacja doświadczenia i własnego rozwoju w związku z wydarzeniem; 3) analiza różnych aspektów tego doświadczenia i jak one wpływają na warsztat nauczycielski; 4) przetwarzanie i porównywanie własnych opinii z opiniami innych; 5) diagnozowanie własnych słabości w myśleniu i działaniu, zastanowienie się nad pytaniem o przyczyny; 6) refleksja nad całością doświadczenia, zastanowienie się nad ewaluacją, co zadziałało, a co nie, gdzie nastąpił rozwój. Po wnikliwej analizie zauważono, że najczęstszym elementem, obecnym w pracach 
studentów, była retrospekcja oraz ewaluacja, a nieobecne były tak ważne elementy, jak: analiza, porównywanie, diagnoza i refleksja. W swoich portfolio studenci opisywali głównie to, z jakimi sytuacjami mieli do czynienia (retrospekcja) i jak sobie z nimi poradzili (szybkie rozwiązanie problemu oraz ewaluacja). Większość opisu skupiona była na rozwiązaniu problemu, a nie na zrozumieniu problemu czy sytuacji i poznaniu swoich przekonań. Poza tym większość opisów dotyczyła wydarzeń z przeszłości, natomiast mało było refleksji na temat wykorzystania tych doświadczeń w przyszłej praktyce nauczycielskiej.

Ostatnio dyskusje na temat refleksji w portfolio toczą się również w kontekście odejścia od czysto technicznych kompetencji nauczyciela, jakie mają być rezultatem pracy z tym narzędziem, w kierunku bardziej osobistych doświadczeń. Refleksja nie jest czynnością odłączoną od emocji i uczuć, co nie jest często wykorzystywane w procesie kształcenia nauczycieli. Portfolio w sposób naturalny łączy się z obszarem przeżyć nauczyciela i odpowiedzią na pytania: Kim jestem? Jakim nauczycielem chcę być? Jak widzę swoją rolę? (Korthagen, Vasalos, 2009; Mejier, Korthagen, Vasalos, 2009). Korthagen i Vasalos (2005) podjęli próbę stworzenia podejścia, w którym przyszły nauczyciel rozwija swoje kompetencje w pewnej łączności i zgodzie z tym, kim jest, co czuje i co go motywuje. Praca z portfolio może więc pomóc w uświadomieniu pewnych ideałów, przekonań związanych z zaistniałą sytuacją, wesprzeć zidentyfikowanie problemów, które stoją na drodze rozwiązania napotkanych trudności, a przede wszystkim pomóc rozpoznać ciężar emocji, który towarzyszy działaniom nauczycielskim.

Dotychczasowe badania potwierdzają, że jakość refleksji towarzyszącej portfolio jest zróżnicowana, ale zależy od działań skupionych wokół procesu tworzenia portfolio. Wymienić tu można na przykład: mentoring, współpracę, dyskusję i dialog, które powinny mieć miejsce podczas pracy nad portfolio, oraz informację zwrotną, którą powinni otrzymywać studenci podczas tworzenia portfolio (Kennedy, 2010). Wzrost umiejętności refleksji podczas pracy z portfolio nie jest tylko związany z samą przestrzenią tworzenia, ale również z aktywnościami skierowanymi na głębokie zrozumienie sensu doświadczeń. Takie aktywności wymagają skoordynowania procesu kształcenia i spójnej wizji edukatorów pracujących ze studentami (Delandshere, Petrosky, 2010). Poprzez dyskusję, informację zwrotną i zadawanie pytań studenci mogą być nakierowywani na alternatywne sposoby rozwiązywania problemów lub mogą być zachęcani do głębszej analizy i refleksji. Portfolio nie kontroluje jakości refleksji, ale może być punktem wyjścia do rozmów i dyskusji, które bez wątpienia mogą wpłynąć na tę jakość. Możliwości, jakie daje portfolio, to także zaobserwowanie różnorodnych kontekstów i różnych źródeł wiedzy, co może naprowadzić do alternatywnych rozwiązań. Nie tylko same 
artefakty, ale i komentarze, notatki i wstępne refleksje dają możliwość rewizyty i ciągłej eksploracji. Portfolio oferuje olbrzymie możliwości tworzenia przestrzeni na własne odkrywanie i refleksję.

Badania wykazały również indywidualne różnice między studentami w zakresie umiejętności wykorzystania procesu w czasie tworzenia portfolio. Zauważono, że chęć zainwestowania studentów w portfolio była podobna do wyników badań nad sposobami uczenia się przez przyszłych nauczycieli. Studenci, którzy byli skupieni na zadaniu i szybkim zakończeniu (ang. immediate performance oriented), nie byli zainteresowani długotrwałą inwestycją, jaką jest portfolio. Natomiast studenci zainteresowani poszukiwaniem znaczeń (ang. meaning oriented) bez problemu zaakceptowali i zaadaptowali portfolio na swoje potrzeby, byli bardziej gotowi na podjęcie analizy swoich działań (Darling, Farr, 2001). Pytanie, które wynika z tych badań, dotyczy kwestii, czy w związku z tak różnym i naturalnym podziałem studentów na tych bardziej zainteresowanych procesem i tych bardziej zainteresowanych produktem - portfolio powinno być wymaganym narzędziem dla wszystkich studentów (Mansvelder-Longaroux, Bejiard, Verloop, 2007). Wpływ na portfolio miał również sposób wprowadzenia i nadzoru przez wykładowców. W dużym badaniu ilościowym, w którym uczestniczyło ponad 200 studentów edukacji wczesnoszkolnej, udowodniono, że studenci wykazali się myśleniem refleksyjnym. Studenci uznali, że proces tworzenia portfolio pozwolił im na lepsze zrozumienie doświadczeń z odbytych praktyk. Byli w stanie połączyć wcześniejsze doświadczenia z ich życia i pracy zawodowej. Tym pozytywnym opiniom towarzyszyły również negatywne. Duża część studentów odczuwała zniechęcenie i niezadowolenie w związku portfolio, zwłaszcza na początku. Największe trudności sprawiały studentom brak wcześniejszych doświadczeń w tworzeniu portfolio, otwarta formuła, która kłóciła się ze ściśle określanymi wymogami prac, które studenci musieli realizować wcześniej, oraz niechęć inwestowania w proces konstrukcji portfolio.

\section{PORTFOLIO I OCENIANIE}

Obok dyskusji na temat refleksji i jej roli przy tworzeniu portfolio literatura przedmiotu dużą uwagę przywiązuje do kwestii oceniania. Portfolio jest zaliczane do tzw. autentycznych sposobów oceniania nauczycieli, czyli ocenianie jest przeprowadzane na podstawie analizy typowych i rzeczywistych działań nauczycielskich (ang. performance based-assesssment). Do takich sposobów oceny nauczycieli obok samego portfolio zalicza się na przykład: narzędzia obserwacyjne, opisy 
przypadków przeprowadzanych przez studentów, symulacje, jak również scenariusze lekcji lub analizy prac uczniów. Takie sposoby oceniania uważane są jako bardziej wartościowe ze względu na ich wiarygodność w kontekście oceny przyszłych nauczycieli. Prezentują one lepiej rzeczywiste umiejętności w obliczu kompleksowości wyzwań związanych z pracą nauczyciela.

Portfolio od zawsze było wyróżniane ze względu na autentyczność i wiarygodność. Pozwala bowiem na prezentację szerokiej wiedzy, umiejętności oraz dyspozycji, które uznaje się jako kluczowe u nauczycieli. Umożliwia ono również zbieranie danych z upływem czasu w różnych kontekstach edukacyjnych. Dodatkowym, pozytywnym elementem jest na przykład to, że może być posumowane przez wielu ekspertów o różnej specjalności, zajmujących się różnymi aspektami kształcenia. Inaczej dane zadanie może być ocenione przez nauczyciela praktyka, a inaczej przez wykładowcę akademickiego (Darling-Hammond, Snyder, 2000).

Portfolio jest stosowane do celów oceniania podsumowującego, jak na przykład portfolio wykorzystywane do decyzji certyfikacyjnych (np. portfolio NBPTS w USA ). Najczęściej wchodzi w skład materiałów, na podstawie których decyzje są podejmowane, a analiza portfolio odbywa się na podstawie jasnych kryteriów i jest przeprowadzana przez wielu przeszkolonych ewaluatorów. Portfolio jest również uznawane jako narzędzie oceniania kształtującego, będące częścią integralną programów kształcenia nauczycieli. Wiele badań potwierdza pozytywne rezultaty wykorzystania portfolio jako takiego narzędzia, które jest integralnie związane z programem kształcenia. Lyons (1998) zauważył, że jakość pierwszych refleksji w portfolio w jego badaniu była mało wnikliwa, natomiast po upływie czasu refleksje w portfolio stawały się bardziej rozbudowane. Badanie to pokazało również, że dialog i współpraca między studentami oraz mentorami podczas tworzenia portfolio znacznie pogłębiły jakość refleksji, a także zwiększyły samoświadomość studentów pod wpływem pracy z portfolio. Dodatkowo konieczność wspólnego rozwiązywania problemów i współpracy z innymi studentami lub nauczycielami nad zadaniami portfolio wymagała odkrywania własnych wartości i przekonań. Ponadto portfolio jest szczególnie wartościowe w procesie oceniania kompetencji związanych z analizą i regulacją własnych potrzeb rozwoju zawodowego, analizy mocnych i słabych stron oraz planowania i refleksji.

Istnieje jednak w przypadku oceniania konflikt między koniecznością wsparcia przez wykładowców lub mentorów, w czasie tworzenia portfolio, a jednocześnie koniecznością wystawienia oceny. Otóż podczas tworzenia portfolio studenci oraz wykładowcy rozwijają często relacje mentorskie, a dialog i bliska współpraca znacznie utrudnia proces rzetelnej oceny pracy studenta nad portfolio. Ocenianie portfolio jest częścią szerszej debaty dotyczącej roli oceniającej osób zajmujących 
się kształceniem nauczycieli. Z jednej strony ich rola polega na wspieraniu rozwoju, a z drugiej strony stają się strażnikami kwalifikacji, odczuwając przy tym wewnętrzny konflikt.

Dodatkowe zastrzeżenia dotyczące rzetelności portfolio polegają na tym, że sami studenci nie są skłonni do przyznania się do swoich słabości, ponieważ może to być uznane jako niekorzystny element w ich ocenianiu, który ostatecznie może doprowadzić do obniżenia ich końcowego wyniku. Poza tym mogą być zainteresowani przedstawieniem jedynie pozytywnego obrazu swoich umiejętności, często nieprawdziwego lub zasugerowanego przez wykładowców.

\section{PRZYKŁAD WPROWADZENIA PORTFOLIO NA KIERUNKU GRADUATE PROGRAMME OF TEACHING ENGLISH TO YOUNG LEARNERS (GPTE)}

Portfolio na kierunku Graduate Programme of Teaching English to Young Learners (GPTE) było częścią kompleksowego przedsięwzięcia, jakim było wypracowanie programu kształcenia nauczycieli wczesnego nauczania języka angielskiego oraz zintegrowanego nauczania językowo-przedmiotowego (CLIL) wprowadzonego w 2015 roku. Program kształcenia GPTE jest skierowany do studentów o bardzo różnych umiejętnościach i doświadczeniach wstępnych. Uczestnikami tych studiów są bowiem osoby z uprawnieniami nauczycielskimi do nauczania języka angielskiego, ale i studenci innych kierunków pedagogicznych z kraju i zagranicy. Tworzenie portfolio było związane z chęcią uaktywnienia studentów w proces własnego konstruowania wiedzy i umiejętności w oparciu o wcześniejsze doświadczenia, rozwój umiejętności samooceny oraz próbę odejścia od pasywnego odbioru wiedzy dzięki rozwojowi umiejętności analizy i refleksji.

Portfolio w programie GPTE w swoim założeniu miało nadać ciągłość procesowi kształcenia zarówno na poziomie programu, poszczególnych modułów, jak i na poziomie indywidualnych doświadczeń, które stopniowo studenci nabywali podczas studiów. Twórcom programu zależało na odejściu od oderwanych części, jakimi często bywają poszczególne zajęcia, w stronę stworzenia spójnego programu kształcenia. Z założenia doświadczenia, z którymi studenci przychodzą na studia, miały być ważnym punktem wyjścia do dalszego procesu uczenia się. Celem całego programu było zatem przygotowanie nauczycieli rozumiejących rolę refleksji i wykorzystujących ją w nauczaniu oraz rozwoju zawodowym (Richards, Lockhart, 1996; Farrell, 2018). Refleksja jest widziana jako umiejętność niezbędna do dalszego kierowania własnym procesem uczenia się i rozwojem (Korthagen, 2001). Portfolio tworzone przez podczas dwuletnich studiów miało 
w swoich zamierzeniach być początkiem refleksyjnej drogi rozwoju zawodowego absolwentów GPTE.

\subsection{WSTĘPNA ANALIZA DOŚWIADCZEŃ}

Początki idei powstania tego narzędzia miały miejsce w 2015 roku w momencie rozpoczęcia planowania nowego programu kształcenia, a w roku 2016 powstały pierwsze indywidualne portfolio stworzone przez studentów. W momencie pisania tej pracy istnieje około 50 przykładów wstępnych wersji portfolio nauczycielskiego GPTE, ponadto odbyły się pierwsze prezentacje portfolio wykorzystane do oceny pracy studentów. Doświadczenia te oraz zawarte materiały stały się podstawą do pierwszych podsumowań, a także do wyznaczenia dalszych kierunków rozwoju.

Dotychczasowe wykorzystanie portfolio w programie GPTE wykazało, że jest ono narzędziem, które daje duże możliwości rozwoju przyszłych nauczycieli, jednocześnie będąc wymagającym zarówno dla samych studentów, jak i wykładowców. Analiza pierwszych materiałów oraz doświadczeń wykazała, że implementacja portfolio GPTE w formie, jaką zaplanowano, wymagała przede wszystkim spójności wewnątrzprogramowej, niezwykle sprawnej organizacji, dużego nakładu indywidualnej pracy ze studentami i przedstawienia studentom wspólnej wizji kształcenia przez wszystkich biorących w niej udział edukatorów - zarówno tych pracujących na uniwersytecie, jak i tych pracujących ze studentami w szkołach. Doświadczenia ukazały również, że portfolio zarówno dla wielu wykładowców, jak i samych studentów było narzędziem nieznanym w ich dotychczasowej edukacji, z którym musieli się zapoznać oraz które musieli zaadaptować do własnych potrzeb przedmiotowych i programowych, a nade wszystko uznać je za wartościowe.

Pierwszy okres implementacji portfolio GPTE był nakierowany na tworzenie mechanizmów, które szczegółowo zintegrują go z resztą programu. Podstawowe cele programowe portfolio GPTE wymagały nadania ciągłości procesowi kształcenia studentów przez budowanie na indywidualnych doświadczeniach oraz podjęcie próby łączenia teorii i praktyki poprzez analizę i refleksję nad tymi doświadczeniami. Inne ważne cele, które przyświecają wykorzystaniu portfolio, to rozwijanie autonomii nauczycielskiej przez zachęcanie do odkrywania znaczeń w poszczególnych doświadczeniach, refleksji, nadawania transparentności procesowi uczenia się oraz nazywanie i pokazywanie celów poszczególnych działań edukacyjnych, jak również rozwijanie świadomości i spójności wyboru działań w klasie (Newby, 2012). 


\subsection{WIELOPOZIOMOWA STRUKTURA PORTFOLIO GPTE}

Portfolio GPTE nie zostało zaplanowane jako odizolowane, jednostkowe narzędzie wykorzystywane jedynie na praktykach, ale podobnie do EPOSTL (2007), jako narzędzie kompleksowe, pojawiające się na poszczególnych kursach, w poszczególnych modułach, oraz jako narzędzie podsumowujące dwuletni proces kształcenia. Chociaż struktura portfolio jest jeszcze doprecyzowywana, w obecnym stanie obejmuje dwa rodzaje narzędzi. Są to portfolio uczenia się i rozwoju (ang. Learning Portfolio) oraz portfolio dla pracodawców (ang. Pedagogical CV). Rozróżnienie tych dwóch okazało się konieczne ze względu na zróżnicowanie celów i oczekiwań. Portfolio uczenia się jest tworzone przez cały okres studiów (2 lata), a portfolio dla pracodawców pod koniec studiów jako prezentacja kompetencji zawodowych w końcowym okresie studiów

Portfolio uczenia się i rozwoju jest tworzone poprzez indywidualną eksplorację tematów i dylematów w nauczaniu języka oraz nauczaniu językowo-przedmiotowym dzieci w obrębie 10 obszarów uznanych za kluczowe w GPTE. Obszary te to: przedmiot i tematyka (wiedza potrzebna do nauczania języka i integracji językowo-przedmiotowej);procesy rozwojowe i edukacyjne dzieci; indywidualne potrzeby i autonomia ucznia; podejścia, metody, techniki oraz strategie nauczania; planowanie procesu nauczania; środowisko edukacyjne; ocenianie; komunikacja w klasie i szkole: wspieranie postawy badawczej, współpracy i współdziałania oraz wzajemnych relacji; refleksja i rozwój zawodowy; współpraca, etyka oraz relacje międzyludzkie. Obszary służą pewnemu uporządkowaniu i organizacji Portfolio.

Portfolio uczenia się składa się z 5 głównych części: z krótkiej autoprezentacji, przedstawienia wizji uczenia się i nauczania. Następnie Portfolio zawiera krótkie prezentacje szkół i programów nauczania języka, z którymi studenci mieli styczność. Celem tych prezentacji jest zwrócenie uwagi studentów na kontekst programowy, społeczny oraz kulturowy poszczególnych szkół.

Kluczowym elementem portfolio są 4-6 opracowane tematy, które zostały wybrane przez studentów jako te, które uznali za ważne i warte dalszej eksploracji. Nie zawsze jednak wybór tematów jest prosty dla studentów, często ogranicza się do wymienienia dobrych praktyk, z którymi się spotkali w czasie zajęć lub podczas swoich doświadczeń w szkołach, często bez uzasadnienia lub głębszej refleksji. Temat w swoim założeniu ma być w miarę zwięzłym i dobrze uzasadnionym obszarem eksploracji. Przykładami takich właściwie uzasadnionych tematów, które pojawiły się w portfolio to: organizacja miejsca i przestrzeni w szkole i ich rola w procesie nauczania języka, rola współpracy w działaniach edukacyjnych, nauczanie komunikacji na lekcjach języka, wyko- 
rzystanie oceniania kształtującego w pracy z małym dziećmi lub komunikacja z rodzicami. Wybór tematów jest często zainicjowanymi własnymi doświadczeniami, pracami i refleksjami z zajęć akademickich. Poszczególne elementy lub etapy tej eksploracji są opisywane, uzasadniane i analizowane poprzez celowo wybrane artefakty i doświadczenia z praktyk, przykłady prac uczniów, przykłady komunikacji z rodzicami. Learning Portfolio zawiera również końcowy esej dotyczący procesu własnego rozwoju.

Takie portfolio jest stworzone pod koniec studiów, jego celem jest jedynie zaprezentowanie wiedzy i umiejętności nabytych w czasie trwania studiów. Portfolio dla pracodawców w mniejszym stopniu skupia się na przedstawieniu procesu uczenia, a raczej prezentuje nabyte umiejętności.

Oba te narzędzia są elektroniczne, tworzone za pomocą ogólnodostępnych i darmowych programów pozwalających na tworzenie portfolio elektronicznych.

\subsection{WYZWANIA ZWIAZZANE Z IMPLEMENTACJĄ PORTFOLIO GPTE}

Największe dotychczasowe problemy polegały na poszukiwaniu rozwiązań związanych z integracją portfolio z nowo tworzonym programem, co przede wszystkim wymagało zaangażowania, a nawet w pewnym stopniu zaufania wykładowców i mentorów do tego narzędzia. Wydaje się, że to zaufanie do portfolio pozwoliło wykładowcom na poświęcenie większej ilości czasu na jego realizację. Jednym z wielkich problemów z wprowadzaniem tego narzędzia jest próba znalezienia miejsca w trakcie poszczególnych zajęć i praktyk. Nie wszyscy wykładowcy mieli wcześniejsze doświadczenia z wykorzystaniem tego narzędzia.

Innym problemem związanym z wprowadzaniem portfolio GPTE był braku dogłębnej dyskusji na temat roli, jaką według wykładowców portfolio GPTE miało odegrać w obrębie ich poszczególnych przedmiotów oraz w obrębie całego programu GPTE. W trakcie pierwszych miesięcy doświadczeń w pracy pojawiła się wartościowa dyskusja o roli wykładowców i sposobach zaangażowania w tym procesie. Kolejnym ważnym elementem w dalszym rozwijaniu portfolio jest poszukiwanie dróg wsparcia dla studentów. Chociaż portfolio GPTE jest indywidualną pracą studentów, to właśnie wsparcie uczniów przez mentorów, opiekunów oraz wykładowców jest kluczowym elementem w procesie tworzenia tych narzędzi. Odbywa się przez odpowiedni dobór zadań w trakcie zajęć, współpracę między studentami, ciągły dialog studentów z wykładowcami oraz wspólną refleksję. Kolejnym wyzwaniem, często wymienianym w literaturze, potwierdzonym w doświadczeniach portfolio GPTE był brak przygotowania studentów do pracy z portfolio. Studenci nie mieli wcześniejszych doświadczeń w pracy z tym narzę- 
dziem. Dodatkowo problematyczne była też otwarta formuła portfolio, wymagająca uaktywnienia i zaangażowania samych studentów we własny proces uczenia się oraz samoceny.

\section{PODSUMOWANIE}

Wstępne próby wykorzystania portfolio GPTE wskazały, że jest to narzędzie, które może pozytywnie wpłynąć na rozwój świadomości i umiejętności samooceny przyszłych nauczycieli, ale musi temu towarzyszyć spełnienie wielu warunków. Pierwszym warunkiem jest głębsza integracja koncepcji portfolio z całym programem kształcenia. Portfolio było narzędziem dopełniającym jasno określone założenia dotyczące kształcenia studentów, a nie odizolowanym zadaniem postawionym przed studentami. Taka rola wymagała współpracy między wszystkimi edukatorami zaangażowanymi w proces kształcenia: wykładowcami na uniwersytecie oraz mentorami w szkołach. Kolejnym warunkiem było poszukiwanie działań oraz możliwości wspierania studentów w celu pogłębienia analizy doświadczeń. Podczas pracy nad tworzeniem portfolio studenci byli zaangażowani we wspólne rozwiązywania problemów i współpracy z innymi w celu odkrywania własnych wartości i przekonań. Prace studentów pokazały, że tworzenie okazji do rozmowy i wymiana doświadczeń w czasie tworzenia portfolio znacznie pogłębiły jakość studenckich refleksji. Doświadczenia tworzenia portfolio na GPTE pokazują, że niespełnienie tych warunków powodowało, że jakość prac studentów była znacznie gorsza, portfolio były jedynie zbiorem dokumentów, a sam proces tworzenia jedynie obowiązkiem.

Proces tworzenia portfolio GPTE potwierdził, że jest ono narzędziem, które wpisuje się w koncepcję uczenia się i nauczania podkreślającą rolę osobistych doświadczeń oraz rekonstrukcji tych doświadczeń podczas procesu kształcenia w celu stworzenia nowych koncepcji nauczycielskich. Pozwala one na otwartą formę procesu kształcenia, a nie zamkniętą, w której z góry wiadomo, czego przyszli nauczyciele muszą się nauczyć. Celem wykorzystania portfolio jest indywidualna eksploracja tematów i dylematów nauczycielskich poprzez ich dokumentowanie, a następnie głęboką analizę i refleksję. W swoich założeniach tworzenie takiego portfolio jest procesem, a praca nad portfolio ma zobrazować proces uczenia się. Portfolio pozwala więc na ciągłą rewizję i reeksplorację doświadczeń, które towarzyszą działaniom przyszłych nauczycieli. 


\section{Bibliografia}

Bain, R., Ballantyne, J.P., Mills, C. (1999). Using journal writing to enhance student teachers' reflectivity during field experience placements. Teachers and Teaching, 5(1), s. 51-73. DOI: 10.1080/1354060990050104.

Conway, P.F. (2001). Anticipatory reflection while learning to teach: From a temporally truncated to a temporally distributed model of reflection in teacher education. Teaching and Teacher Education, 17, s. 89-106.

Darling Farr, L. (2001). Portfolio as practice: The narratives of emerging teachers. Teaching and Teacher Education, 17, s. 107-121.

Darling-Hammond, L., Snyder, J. (2000). Authentic assessment of teaching in context. Teaching and Teacher Education, 16, s. 523-545.

Delandshere, G., Arens, S. (2003). Examining the quality of the evidence in preservice teacher portfolios. Journal of Teacher Education, 54(1), s. 57-73.

Delandshere, G., Petrosky, A. (2010). The use of portfolios in preservice teacher education: A critical appraisal. W: M. Kennedy (red), Teacher Assessment and The Quest for Teacher Quality: A Handbook (s. 9-42). San-Francisco: Jossey-Bass.

Farrell, T.C.S. (2018). Reflective practice for language teachers. W: J.I. Liontas (red.), The TESOL Encyclopedia of English Language Teaching (s. 1-6). Hoboken, NJ: John Wiley \& Sons.

Habib, L., Wittek, L. (2007). The portfolio as artifact and actor. Mind, Culture, and Activity, 14(4), s. 266-282.

Ingvarson, L.C., Hattie, J. (2008). Assessing teachers for professional certification: The first decade of the National Board for Professional Teaching Standards, (Vol. II). Amsterdam: Elsevier Press.

Kennedy, M. (2010). The Uncertain Relationship Between Teacher Assessment and Teacher Quality. W: M. Kennedy (red.), Teacher Assessment and the Quest for Teacher Quality: A Handbook (s. 1-6). San Francisco: Jossey-Bass.

Korthagen, F.A.J. (2001). Linking practice and theory: The pedagogy of realistic teacher education. Lawrence Erlbaum Associates Publishers.

Korthagen, F.A.J., Vasalos, A. (2010). Going to the core: Deepening reflection by connecting the person to the reflection. W: N. Lyons (red.), Handbook of reflection and reflective inquiry. Mapping a way of knowing for professional reflective inquiry (s. 531-554). New York: Springer.

Lyons, N. (1998). Reflection in teaching: can it be developmental? A portfolio perspective. Teacher Education Quarterly, 25, s. 115-127.

Mansvelder-Longayroux, D., Beijaard, D., Verloop, N. (2007). The portfolio as a tool for stimulating reflection by student teachers. Teaching and Teacher Education, 23, s. 47-62.

Meeus, W., Questier, F., Derks, T. (2006). Open source eportfolio: development and implementation of an institution-wide electronic portfolio platform for students. Educational Media International, 43(2), s. 133-145. DOI: 10.1080/09523980600641148.

Meeus, W., Van Petegem, P., Van Looy, L. (2006). Portfolio in higher education: time for a clarificatory framework. International Journal of Teaching and Learning in Higher Education, 17(2), s. 127-135. 
Meijer, P.C., Korthagen, F., Vasalos, A. (2009). Supporting presence in teacher education: The connection between the personal and professional aspects of teaching. Teaching and Teacher Education, 25(2), s. 297-308. DOI: https://doi.org/10.1016/j.tate.2008.09.013.

Newby, D., Allan, R., Fenner, A.-B., Jones, B., Komorowska, H., Soghikyan, K. (2006). European portfolio for student teachers of languages. Graz: European Centre for Modern Languages of the Council of Europe.

Richards, J., Lockhart, C. (1996). Reflective teaching in second language classrooms. Cambridge: Cambridge University Press.

Shulman, L.S., Sykes, G. (1986). A national board for teaching? In search of a bold standard. Paper prepared for the Task Force on Teaching as a Profession. Carnegie Forum on Education and the Economy.

Smith, K., Tillema, H. (2001). Long term influences of portfolios on professional development. Scandinavian Journal of Educational Research, 45(2), s. 183-203.

Smith, K., Tillema, H. (2003). Clarifying different types of portfolio use. Assessment \& Evaluation in Higher Education, 28(6), s. 625-648. DOI: 10.1080/0260293032000130252.

Tanner, R., Longayroux, D., Beijaard, D., Verloop, N. (2000). Piloting portfolios: using portfolios in pre-service teacher education. ELT Journal, 54(1), s. 20-30. DOI: https:// doi.org/10.1093/elt/54.1.20.

Wade, R., Yarbrough, D. (1996). Portfolios: a tool for reflective thinking in teacher education. Teaching and Teacher Education, 12(1), s. 63-79.

Wolf, K., Dietz, M. (1998). Teaching Portfolios in Teacher Education. Teacher Education Quarterly, 25(1). s. 9-22.

Zeichner, K., Liston, D.P. (1987). Teaching student teachers to reflect. Harvard Educational Review, 57, s. 23-48.

Zeichner, K., Wray, S. (2001). The teaching portfolio in us teacher education programs: what we know and what we need to know. Teaching and Teacher Education, 17, s. 613-621. DOI: http://dx.doi.org/10.1016/S0742-051X(01)00017-8. 